\title{
The comparison of the actual cost to case-mix of type 2 diabetes mellitus inpatient in Pandan Arang Boyolali hospital
}

\author{
Sri Bintang Sahara Mahaputra Kusuma Negara, Devi Ristian Octavia, Primanitha Ria Utami \\ Departement of Pharmacy, Faculty of Health Sciences, Universitas Muhammadiyah Lamongan, Indonesia
}

\author{
Keywords \\ Actual cost \\ Cost analysis \\ Diabetes Mellitus \\ Factor analysis \\ INA-CBGs

\section{Correspondence} \\ Sri Bintang Sahara Mahaputra Kusuma Negara \\ Departement of Pharmacy \\ Faculty of Health Sciences \\ Universitas Muhammadiyah Lamongan \\ Indonesia \\ devioctavia1987@gmail.com
}

\begin{abstract}
Aim: The objective of this study was to determine the conformity of diabetes mellitus (DM) actual cost with the rate of Indonesia Case-Based Groups (INA-CBGs) among Universal Health Coverage (Jaminan Kesehatan Nasional - JKN) and non-JKN patients diagnosed with DM. Methods: This retrospective cross-sectional study was observational and analytic. It recruited DM inpatients with or without JKN. The data were analysed to identify the total actual cost of DM management among inpatients. Results: The results showed that the average cost for treating inpatient with diabetes mellitus at classes 1,2 , and 3 was IDR 2,677,003 $\pm 906,406$, IDR $2,881,023 \pm 851,483$, and IDR $2,323,768 \pm 802,828$, respectively. A positive difference of $378,509,126$ was found between the actual cost and the INA-CBGs rate in 101 patients. There was a discrepancy between the real cost and the INA-CBGs rate for all treatment classes and the treatment levels. Factors influencing the real cost of treatment for DM were the length of stay and the severity level.
\end{abstract}

\section{Introduction}

Diabetes mellitus is a chronic disease that has become a global health problem. Several epidemiological studies showed an increased tendency of the incidence and prevalence of diabetes in various parts of the world. The World Health Organization (WHO) has categorized diabetes mellitus as a global disease. Statistical data estimated that 382 million adult people have diabetes; this number is expected to increase and reach 592 million by 2035 . The growing diabetes problem presents a potential challenge to the development of health systems and economies in developing countries (Belma et al., 2019).

Diabetes mellitus is known as the silent killer as it can attack all organs of the body and cause different complications, such as visual disturbances (including cataracts), heart disease, kidney disease, impotence, long-healing wounds (including gangrene), lung infections, blood vessel disorders, and stroke. Lifestyle modifications and medication intake reduce the incidence and severity of type 2 diabetes mellitus (T2DM) (American Diabetes Association, 2014).

A study conducted in 2014 estimated that in 2020 diabetes mellitus will increase the economic burden in Indonesia to exceed 1.27 billion. Health costs, the growing burden of diabetes mellitus, and the severity of rapidly evolving chronic complications have a significant long-term detrimental impact on health development and national economic growth (Finkelstein et al., 2014).

Currently, the Indonesian government has implemented the National Health Insurance Programme known as JKN. The JKN programme aims to reform the health sector to overcome problems related to public health, limiting uncontrolled health costs and improving service quality (Eko Wahyu Basuki et al., 
2016). The Social Security Administering Body (BPJS) is a legal entity established to administer the JKN programme. The implementation of the BPJS programme in hospital services uses the INA-CBGs system (Indonesia Case-Based Groups). The INA-CBGs system is guided by the INA-CBGs rate, namely the number of claim payments by BPJS Kesehatan to health facilities for service packages based on the disease diagnosis and procedure groupings (Kemenkes, 2014).

The evaluation of the actual economic burden of the disease will provide a basis for the government for the long-term fiscal impact of chronic diseases for economic efficiency and the development of strategies, policies, or programmes on the health financing system (Zhuo et al., 2013).

The economic burden of diabetes should be a concern of the National Health Insurance (JKN) implementation in the management of non-communicable diseases. Therefore, it is necessary to analyse the cost of diabetes mellitus. The objective of this study was to determine the conformity of diabetes mellitus (DM) actual cost with the rate of Indonesia Case-Based Groups (INACBGs) among Jaminan Kesehatan Nasional (JKN) and non-JKN patients diagnosed with DM at the Pandan Arang Boyolali hospital in 2017.

\section{Methods}

This retrospective cross-sectional study was observational and analytic with descriptive purposes. Data were collected from the medical records, the actual hospital fees, the case-mix system, and INA-CBG financing claims for inpatients with T2DM, with or without comorbidities, admitted at the Pandan Arang hospital Boyolali between January and December 2017. The data obtained were analysed using descriptive and quantitative methods. The study included JKN and nonJKN in patients with diabetes mellitus coded INA-CBGs E-4-10-I, E-4-10-II, and E-4-10-III.

\section{Inclusion criteria}

Medical record data of JKN patients diagnosed primarily with T2DM, claim files, and patient medical records with diagnostic codes INA-CBG's E-4-10-I, E-410-II, and E-4-10-III, complete details of claim filing fees, data for non-JKN patients diagnosed with T2DM based on details of treatment costs and classes.

\section{Exclusion criteria}

Medical record data of patients who died, patients discharged against medical advice, and incomplete patient data.

\section{Results}

Patient characteristics (Table I), according to the gender distribution, showed that females outnumbered males $(60.4 \%$ in JKN patients and $66 \%$ in non-JKN patients).

\section{Table I: Patients' characteristics}

\begin{tabular}{|c|c|c|c|c|}
\hline \multirow[t]{2}{*}{ Characteristics } & \multicolumn{2}{|c|}{$\begin{array}{c}\text { JKN } \\
\text { patients }\end{array}$} & \multicolumn{2}{|c|}{$\begin{array}{l}\text { Non-JKN } \\
\text { patients }\end{array}$} \\
\hline & $\mathrm{n}$ & $\%$ & $\mathrm{n}$ & $\%$ \\
\hline \multicolumn{5}{|l|}{ Age } \\
\hline $12-25$ & 4 & 3.96 & - & - \\
\hline $26-45$ & 6 & 5.94 & 5 & 11.36 \\
\hline $46-65$ & 67 & 66.33 & 23 & 52.28 \\
\hline$>66$ & 24 & 23.77 & 16 & 36.36 \\
\hline \multicolumn{5}{|l|}{ Gender } \\
\hline Male & 40 & 39.6 & 15 & 34 \\
\hline Female & 61 & 60.4 & 29 & 66 \\
\hline \multicolumn{5}{|l|}{ Secondary diagnosis } \\
\hline E11.0 (diabetes mellitus) & 18 & 40.91 & 30 & 29.71 \\
\hline G73.0 (amyotrophic) & 2 & 4.55 & 7 & 6.93 \\
\hline G63.2 (polyneuropathy) & 1 & 2.27 & 3 & 2.97 \\
\hline \multicolumn{5}{|l|}{ H36.0 (retinopathy) } \\
\hline \multicolumn{5}{|l|}{ H28.0 (cataract) } \\
\hline N08.3 (diabetic nephropathy) & 9 & 20.45 & 14 & 13.86 \\
\hline G99.0 (autonomic nephropathy) & 1 & 2.27 & 6 & 5.94 \\
\hline M14.2 (diabetic arthropathy) & 2 & 4.55 & 11 & 10.89 \\
\hline $\begin{array}{l}\text { M14.6 (neuropathic diabetic } \\
\text { arthropathy) }\end{array}$ & 3 & 6.82 & 15 & 14.85 \\
\hline I79.2 (peripheral angiopathy) & 3 & 6.82 & 5 & 4.95 \\
\hline $\mathrm{N} 08.3+179.2$ & 1 & 2.27 & 3 & 2.97 \\
\hline N08.3 + G99.0 & 2 & 4.55 & 2 & 1.98 \\
\hline N08.3 + M14.2 & 1 & 2.27 & 1 & 0.99 \\
\hline $\mathrm{N} 08.3+\mathrm{H} 28.0$ & & & 1 & 0.99 \\
\hline $\mathrm{N} 08.3+\mathrm{G} 73.0$ & & & 1 & 0.99 \\
\hline N08.3 + M14.6 & 1 & 2.27 & 2 & 1.98 \\
\hline G99.0 + 179.2 & 1 & 2.27 & & \\
\hline
\end{tabular}

These results were in line with those of Masni (2013), where the number of female patients with diabetes mellitus was greater than that of males $(66.7 \%$ and $33.3 \%$, respectively). According to Mauvais-Jarvis (2017), women are at higher risk of developing diabetes because, physically, they are more likely to increase their body mass index due to hormonal processes, i.e. monthly cycle syndrome (premenstrual syndrome) and post-menopause, both facilitating the accumulation of body fat and favouring the occurrence of T2DM in women. This finding is in line with that of Hein and the 
authors (2018), reporting a higher incidence of diabetes among women. Regarding age, most participants with T2DM belonged to the $46-65$ years age group $(66.33 \%$ of JKN patients and $52.28 \%$ of non-JKN patients). Most diabetes patients were $40-59$ years old, and $80 \%$ of patients in this age group were from developing countries, such as Indonesia. However, people less than 45 years old can have diabetes (Yosmar et al., 2018). The results of this study were in line with those of the Association (2013), reporting that age over 45 years was a risk factor for diabetes mellitus due to a poor lifestyle, including unhealthy diet, lack of exercise, and lack of rest. With age, the risk of developing diabetes mellitus increases due to decreased glucose tolerance associated with reduced sensitivity of peripheral cells to the effects of insulin (Wahyuni et al., 2012).

Patients with T2DM, particularly hospitalised patients, are mostly followed for comorbidities and complications in the secondary diagnosis due to longtime uncontrolled blood sugar levels during prediabetes. The most common complication is neuropathy, i.e. distal symmetric polyneuropathy, also known as neuropathic diabetes. Neuropathic diabetes is a sensory loss that starts distally and is characterized by the onset of pain (Feldman et al., 2019). The findings from this study showed that most patients with T2DM had one or two secondary diagnoses. Most of the patients with T2DM have at least one complication (Zheng et al., 2018).

Usually, hospitalised T2DM patients have various comorbidities and complications due to long-time uncontrolled blood sugar levels (Wahyuni et al., 2012). Increased mortality and morbidity of these patients are caused by different macrovascular and microvascular complications that develop during the disease, especially when glucose control is poor. At the macrovascular level, T2DM patients experience hypertension and systemic heart disease more facilely. Tissue damage at the microvascular level is a primary factor in the progression of diabetic nephropathy and neuropathy (Association, 2013).

Table II shows that, among non-JKN patients, the highest average length of stay (LOS) was 1-4 days (26 patients, $59.09 \%$ ), followed by $5-8$ days (15 patients, $34.09 \%$ ), and $>8$ days ( 3 patients, $6.82 \%$ ). This finding indicates that T2DM patients without a secondary diagnosis had the lowest average LOS as they were treated at the Pandan Arang Boyolali Hospital, and all participants recruited from this site had no comorbidities. LOS is an essential indicator in determining the success of therapy for diabetes mellitus patients; it is related to the cost of care incurred by the patient. The shorter the time a patient is hospitalised, the more effective and efficient the service from the hospital is (Salim et al., 2019). Predictor factors that influence LOS are patient characteristics, clinical conditions, medical action, patient management, and hospital administration problems (Lubis \& Susilawati, 2018).

Table II: Length of stay distribution characteristics of JKN and non-JKN patients in 2017

\begin{tabular}{llcc}
\hline Type & Characteristics & $\mathbf{n}$ & $\mathbf{( \% )}$ \\
\hline Non JKN & 1-4 days & 26 & 59.09 \\
& 5-8 days & 15 & 34.09 \\
& $>8$ days & 3 & 6.82 \\
\hline JKN & $1-4$ days & 68 & 67.32 \\
& 5-8 days & 32 & 31.69 \\
& $>8$ days & 1 & 0.99 \\
\hline
\end{tabular}

\section{Real cost compatibility with INA-CBG rates}

Based on the results obtained in Table III, there is a positive difference between the actual cost and INACBG rates at all severity levels because the INA-CBGs rates are higher than the actual cost.

Table III: The difference between total real cost and INA CBG rates for classes 1,2 and 3 at severity level I / II / III

\begin{tabular}{lllccc}
\hline Class & Category & $\mathbf{n}$ & $\begin{array}{c}\text { Total actual cost } \\
\text { (IDR) }\end{array}$ & $\begin{array}{c}\text { Total INA-CBGs rates } \\
\text { (IDR) }\end{array}$ & Difference (IDR) \\
\hline 1 & E-4-10-I & 9 & $16,481,701$ & $46,267,200$ & $29,785,499$ \\
& E-4-10-II & 16 & $38,573,062$ & $114,932,800$ & $76,359,738$ \\
& E-4-10-III & 14 & $49,348,351$ & $124,822,600$ & $75,474,249$ \\
3 & E-4-10-II & 12 & $27,034,770$ & $73,885,200$ & $46,850,430$ \\
& E-4-10-I & 14 & $16,770,430$ & $51,408,000$ & $34,637,570$ \\
& E-4-10-II & 18 & $32,584,700$ & $87,225,300$ & $54,640,600$ \\
& E-4-10-III & 18 & $41,134,960$ & $101,896,000$ & $60,761,040$ \\
\hline
\end{tabular}


The highest difference was at the second severity level IDR 76,359,738, because this level II included 16 episodes of treatment. Patients with severity II required lower medical costs and a shorter LOS than those from level III who had a more complex condition. The high difference found in class 1 severity levels II and III, reaching IDR 76,359,738 and IDR 75,474,249, was due to the use of the average cost of T2DM in these levels (IDR 2,410,816 and IDR 3,524,882, respectively) see Table IV. Regarding patients at the Pandan Arang Boyolali hospital, the complications occurred during their hospitalisation, and they were treated accordingly. Thus, the INA-CBGs package automatically moved according to the rate of the most widely used treatment. Also, the smallest difference (IDR
$29,785,499)$ was seen at the first level of severity because this level had nine episodes of treatment. This finding indicates that patients with severity III required more medical costs and a longer LOS, incurring more costs and less cost difference. Salim and the authors (2019) reported a significant difference in the average LOS between T2DM patients who experienced complications and those who did not. The difference in LOS affected the costs incurred by patients undergoing treatment in the hospital. The difference in the cost of therapy for T2DM patients with complications was influenced by the type of complication, the number of episodes of patient visits, and the different drugs used for each complication (Kusuma et al., 2019).

Table IV: The comparison between average real cost and INA-CBG rates for classes 1, 2, and 3 at the I / II / III severity levels

\begin{tabular}{|c|c|c|c|c|c|c|}
\hline Class & Level of care & Cost & Average (IDR) & $\begin{array}{l}\text { Min } \\
\text { (IDR) }\end{array}$ & $\begin{array}{l}\text { Max } \\
\text { (IDR) } \\
\end{array}$ & $p$ \\
\hline \multirow[t]{6}{*}{1} & E-4-10-I & Actual cost & $1,831,300$ & $1,010,315$ & $2,949,902$ & 0.0001 \\
\hline & & INA CBGs Cost & $5,140,800$ & & & \\
\hline & E-4-10-II & Actual cost & $2,410,816$ & $1,594,440$ & $3,359,498$ & 0.0001 \\
\hline & & INA CBGs Cost & $7,183,300$ & & & \\
\hline & E-4-10-III & Actual cost & $3,524,882$ & $2,529,622$ & $4,791,366$ & 0.0001 \\
\hline & & INA CBGs Cost & $8,915,900$ & & & \\
\hline \multirow[t]{2}{*}{2} & E-4-10-II & Cost Real & $2,252,897$ & $1,653,970$ & $3,724,285$ & 0.0001 \\
\hline & & INA CBGs Cost & $6,157,100$ & & & \\
\hline \multirow[t]{6}{*}{3} & E-4-10-I & Actual cost & $1,197,887$ & 705,760 & $1,543,379$ & 0.0001 \\
\hline & & INA CBGs Cost & $3,672,000$ & & & \\
\hline & E-4-10-II & Actual cost & $1,810,261$ & $1,200,681$ & $2,834,460$ & 0.0001 \\
\hline & & INA CBGs Cost & $5,130,, 900$ & & & \\
\hline & E-4-10-III & Actual cost & $2,285,275$ & $1,195,902$ & $3,186,447$ & 0.0001 \\
\hline & & INA CBGs Cost & $6,368,500$ & & & \\
\hline
\end{tabular}

This study showed a positive difference between the actual cost and INA-CBGs rates due to the conformity of medical procedures with the standards for an efficient and effective impact on patients and hospitals. The results of this study were consistent with those of Sari (2014), stating that the positive difference between actual costs and INA-CBGs rates demonstrates there was an effort to save on financing services for both hospitals and patients.

The INA-CBGs rates package provided was higher than the average actual cost of hospitalisation, serving the hospital because it had succeeded in providing therapy to patients effectively and efficiently. The remaining claims obtained by the hospital could be used: first, to cover or cross-subsidise patients whose total actual cost exceeded that of the INA-CBGs package and, second, as revenue for the hospital itself. The results of this study were in line with those of Sari (2014), who stated that the average actual cost of the I / II / III severity levels was lower than the INA-CBG package.

The treatment performed on JKN and non-JKN patients had differing costs, higher in non-JKN patients, lying in the medical action, including the charge of doctor's visits and the treatment. Besides, there were also differences in the costs of drugs and medical devices incurred by non-JKN patients, which were higher than those of JKN patients. In non-JKN patients, doctors could select more diverse drugs than JKN patients who were prescribed medications only from BPJS claims. The results of this study were in line with those of Islam \& Rusdi (2014), reporting that the cost of inpatient treatment for T2DM patients was higher for non-JKN patients. 


\section{Factors affecting the actual cost}

Table $V$ shows a significant relationship between the severity level and LOS. It also reveals a significant relationship between severity levels and actual costs ( $p$ $=0.0001)$, with a moderate correlation $(r=0.600)$. The higher the severity of the patient, the longer the treatment needed. Therefore, patients received more treatments resulting in more costs, including supporting examinations, medical treatment, and hospitalisation. Overall, the services provided increased the total actual cost received by patients (Labovitz et al., 2016).

Table V: Results of the bivariate correlation analysis of factors affecting the real cost of inpatient diabetes mellitus treatment

\begin{tabular}{lccc}
\hline Factor & $\mathbf{n}$ & $\boldsymbol{r}$ & $\boldsymbol{p}$ \\
\hline Age & 101 & 0.152 & 0.129 \\
Secondary diagnosis & & -0.047 & 0.640 \\
Severity & & 0.600 & 0.0001 \\
LOS (Length of stay) & & 0.352 & 0.0001 \\
Gender & & 0.018 & 0.855 \\
\hline
\end{tabular}

Regarding LOS, the values of $p=0.0001$ and $r=0.352$ indicate a significant relationship between the secondary diagnose and the actual cost and a weak correlation. This result is in line with that of Juaella (2013), reporting that the longer the LOS, the more medical treatment performed, the more medicines needed to overcome the disease, and the more supporting examination costs, drug costs, and accommodation costs. Therefore, as a whole, it could increase the total actual cost.

\section{Conclusion}

Average actual costs of type 2 diabetes mellitus from the perspective of Pandan Arang Boyolali Regional Hospital for JKN patients for classes 1,2 , and 3 is 2,677,003 RP, 2,881,023 RP, and 2,323,768 RP, respectively. For non-JKN patients these costs are 3,301,001 RP, 2,597,435 RP, and 2,841,569 RP for classes 1,2 , and 3 , respectively (Table VI).

For the actual cost with the INA-CBG rate, there is a difference in the total cost of JKN inpatients, which is significantly different among 101 patients. The actual cost at class 1 level I / II / III is 1,831,300 RP, 2,410,816 $\mathrm{RP}$, and 3,524,882 RP, respectively, while, at class 1 , the second level of severity was 2,252,897 RP, and, at class 3 , the I / II / III severity levels were 1,197,887 RP, $1,810,261 \mathrm{RP}$, and 2,285,275 RP, respectively. This difference shows a positive indication, where the total actual cost is lower than the INA-CBG rate. Meanwhile, for the 44 non-JKN patients, the average actual costs at classes 1, 2, and 3 were 3,301,001 RP, 2,597,435 RP, and $2,841,569 \mathrm{RP}$, respectively.

Factors affecting the actual cost are LOS and the severity of type 2 diabetes mellitus coded INA-CBGs E4-10.

Table VI: Comparison between the average actual cost of JKN and non-JKN patients

\begin{tabular}{|c|c|c|c|c|c|}
\hline Type of payment & Average (IDR) & $\pm \mathrm{SD}$ & Min (IDR) & $\operatorname{Max}($ IDR) & $p$ \\
\hline \multicolumn{6}{|l|}{ Class 1} \\
\hline JKN & $2,677,003$ & 906,406 & $1,010,315$ & $4,791,366$ & 0.102 \\
\hline Non JKN & $3,301,001$ & $1,589,700$ & $1,419,904$ & $8,976,332$ & \\
\hline \multicolumn{6}{|l|}{ Class 2} \\
\hline JKN & $2,881,023$ & 851,483 & $1,653,970$ & $3,724,285$ & 0.810 \\
\hline Non JKN & $2,597,435$ & 736,575 & $1,310,853$ & $3,993,891$ & \\
\hline \multicolumn{6}{|l|}{ Class 3} \\
\hline JKN & $2,323,768$ & 802,828 & 705,760 & $3,186,447$ & 0.0001 \\
\hline Non JKN & $2,841,569$ & $2,889,817$ & 990,030 & $10,593,021$ & \\
\hline
\end{tabular}

\section{Acknowledgements}

The authors thanked LPPM Muhammadiyah University Lamongan for supporting this research so that this research could be completed according to the predetermined target.
The authors thanked the director of Pandan Arang Boyolali regional hospital for allowing our team to carry out this research. 


\section{References}

American Diabetes Association. (2014). Diagnosis and classification of diabetes mellitus. In Diabetes Care (Vol. 37, Issue SUPPL.1). https://doi.org/10.2337/dc14-S081

Asosiation, A. D. (2013). Diagnosis and classification of diabetes mellitus. Diabetes Care, 36(SUPPL.1), 67-74. https://doi.org/10.2337/dc13-S067

Belma Malanda, Suvi Karuranga, Pouya Saeedi, P. S. (2019) IDF Diabetes Atlas Ninth edition 2019. International Diabetes Federation, 1

Eko Wahyu Basuki, Sulistyowati, Retno, N., \& Herawati. (2016). Implementasi Kebijakan Jaminan Kesehatan Nasional oleh BPJS Kesehatan di Kota Semarang. Diponegoro Journal Of Social And Political Of Science Tahun 2016, 5(4), 1-11

Feldman, E. L., Callaghan, B. C., Pop-Busui, R., Zochodne, D. W., Wright, D. E., Bennett, D. L., Bril, V., Russell, J. W., \& Viswanathan, V. (2019). Diabetic neuropathy. Nature Reviews. Disease Primers, 5(1), 41. https://doi.org/10.1038/s41572-019-0092-1

Finkelstein, E. A., Chay, J., \& Bajpai, S. (2014). The economic burden of self-reported and undiagnosed cardiovascular diseases and diabetes on Indonesian households. PLOS ONE, 9(6). https://doi.org/10.1371/journal.pone.0099572

Hein, M., Lanquart, J.-P., Loas, G., Hubain, P., \& Linkowski, P. (2018). Prevalence and Risk Factors of Type 2 Diabetes in Major Depression: A Study on 703 Individuals Referred for Sleep Examinations. Psychosomatics, 59(2), 144-157. https://doi.org/10.1016/j.psym.2017.11.003

Islam, Z., \& Rusdi, N. K. (2014). Analisis Perbedaan Pengobatan Diabetes Melitus Tipe II pada Pasien Bpjs Dan Pasien Umum the Analysis Different of Treatment Diabetes Mellitus Type li on General Patients and National Health Insurance Patients (Bpjs ). 151-161

Juaella, A. (2013). Analisis Biaya Pengobatan Infeksi Saluran Kemih Pada Pasien Rawat Inap di RSUD Sawerigading Kota Palopo Provinsi Sulawesi Selatan Tahun 2012 (F. F. U. S. Budi (ed.))

Kemenkes. (2014). Peraturan Menteri Kesehatan Republik Indonesia No.28 Tahun 2014 tentang Pedoman Pelakasanaan Program Jaminan Kesehatan Nasional

Kusuma, E., Darmawan, E., \& Perwitasari, D. A. (2019). Cost of Illness Diabetes Mellitus Tipe 2 dan Komplikasinya pada Peserta Jaminan Kesehatan Nasional (JKN) di Rawat Jalan Rumah Sakit Condong Catur Yogyakarta Cost of Illness Type 2 Diabetes Mellitus and Its Complications in National Health Insurance at Ou. Farmasi Indonesia, 16(2), 89-101

Labovitz, J. M., Shofler, D. W., \& Ragothaman, K. K. (2016). The impact of comorbidities on inpatient Charcot neuroarthropathy cost and utilization. Journal of Diabetes and Its Complications, 30(4), 710-715. https://doi.org/10.1016/j.jdiacomp.2016.01.004

Lubis, I. K., \& Susilawati, S. (2018). Analisis Length of Stay (Los) Berdasarkan Faktor Prediktor Pada Pasien DM Tipe II di RS PKU Muhammadiyah Yogyakarta. Jurnal Kesehatan Vokasional, 2(2), https://doi.org/10.22146/jkesvo.30330
Masni, D. (2013). Cost analysis of type 2 diabetes mellitus inpatient hospital RSD of dr Soebandi Jember in the period of 2012. In Thesis. Universitas Setia Budi

Mauvais-Jarvis, F. (2017). Epidemiology of Gender Differences in Diabetes and Obesity. Advances in Experimental Medicine and Biology, 1043, 3-8. https://doi.org/10.1007/978-3-319-70178-3_1

Salim, M. F., Lubis, I. K., \& Sugeng, S. (2019). Perbedaan Length of Stay (LOS) Pasien Diabetes Mellitus Berdasarkan Komplikasi Di RSUP Dr. Sardjito Yogyakarta. Jurnal Manajemen Informasi Kesehatan Indonesia, 7(1), 17. https://doi.org/10.33560/jmiki.v7i1.216

Sari, R. P. (2014). Perbandingan biaya riil dengan tarif paket ina - cbg's dan analisis faktor yang mempengaruhi biaya riil pada pasien. Jurnal Spread, 4(April), 61-70

Wahyuni, N. K. E., L, L. P. F., \& Udayani, N. N. W. (2012). Analisis Efektivitas Biaya Penggunaan Terapi Kombinasi Insulin Dan Oho Pada Pasien Diabetes Melitus Tipe 2 Rawat Jalan Di Rsud Wangaya. Dm, 30-37

Yosmar, R., Almasdy, D., \& Rahma, F. (2018). Survei Risiko Penyakit Diabetes Melitus Terhadap Masyarakat Kota Padang. Jurnal Sains Farmasi \& Klinis, 5(2), 134. https://doi.org/10.25077/jsfk.5.2.134-141.2018

Zheng, Y., Ley, S. H., \& Hu, F. B. (2018). Global aetiology and epidemiology of type 2 diabetes mellitus and its complications. Nature Reviews. Endocrinology, 14(2), 88-98. https://doi.org/10.1038/nrendo.2017.151

Zhuo, X., Zhang, P., \& Hoerger, T. J. (2013). Lifetime direct medical costs of treating type 2 diabetes and diabetic complications. American Journal of Preventive Medicine, 45(3), 253-261. 